\title{
Identification and Quantification of Polymyxa graminis f. sp. temperata and $P$. graminis f. sp. tepida on Barley and Wheat
}

\author{
C. Vaïanopoulos, C. Bragard, V. Moreau, H. Maraite, and A. Legrève, Unité de phytopathologie, Université ca-
} tholique de Louvain (UCL), Croix du Sud 2/3, Louvain-la-Neuve 1348, Belgium

\begin{abstract}
Vaïanopoulos, C., Bragard, C., Moreau, V., Maraite, H., and Legrève, A. 2007. Identification and quantification of Polymyxa graminis f. sp. temperata and P. graminis f. sp. tepida on barley and wheat. Plant Dis. 91:857-864.

Polymyxa graminis f. sp. temperata and P. graminis f. sp. tepida are distinguished on the basis of their specific ribosomal DNA sequences. In order to evaluate whether or not host specialization is associated with the special form, the occurrence of infection of both forms on barley and wheat was studied. P. graminis inocula were obtained from soils collected in Belgium and France. Their ribotypes were characterized using molecular tools specific to $P$. graminis $\mathrm{f}$. sp. temperata or $P$. graminis f. sp. tepida such as restriction fragment length polymorphism (RFLP) analysis of polymerase chain reaction (PCR)-amplified rDNA, nested and multiplex PCR. Both special forms were found in each country and coexisted in some soils. The host specificity of $P$. graminis special forms for barley and wheat was studied from two soils collected at Gembloux (Belgium) and Chambon-sur-Cisse (France), each infested by bymo- and furoviruses. $P$. graminis f. sp. temperata is more frequent on barley and $P$. graminis $\mathrm{f}$. sp. tepida on wheat. Furthermore, the quantification of each form on barley and wheat by two separated real-time quantitative PCR assays confirms the observations on the vector specialization. These results suggest a certain but not exclusive host specificity of $P$. graminis special forms.
\end{abstract}

Additional keyword: plasmodiophorid

The plasmodiophorid Polymyxa graminis Ledingham is a ubiquitous obligate root endoparasite. $P$. graminis transmits at least 14 virus species from the genera Beny-, Bymo-, Furo-, and Pecluvirus, causing major diseases and significant yield losses in cereals in both temperate and tropical regions $(1,10,17)$.

Polymyxa belongs to the kingdom Protista and the order Plasmodiophorales. Its taxonomic position is a matter of debate and was reviewed recently (4,6). Molecular and ecological characterization $(11,20$, 27,28 ) have shown a high level of diversity of $P$. graminis isolates, leading to the distinction of five special forms of $P$. graminis (11), with specific ribotypes and ecological features. Two special forms, $P$. graminis f. sp. temperata and $P$. graminis f. sp. tepida, occur in temperate areas and are characterized by strongly differing ribotypes $(11,29)$.

$P$. graminis is found mainly on a wide range of Gramineae, including barley, oats, pearl millet, rice, rye, sorghum, and wheat $(2,15,19)$. Host range studies involving

Corresponding author: C. Vaïanopoulos

E-mail: vaianopoulos@fymy.ucl.ac.be

Accepted for publication 29 January 2007.

doi:10.1094/PDIS-91-7-0857

(c) 2007 The American Phytopathological Society barley, oats, rye, and wheat have revealed different levels of susceptibility to $P$. graminis isolates from various countries (Belgium, Canada, France, Germany, India, Pakistan, Senegal, and the United Kingdom) depending on the cultivars/species tested $(2,5,15)$.

Differences in the host range and the ability to parasitize cereal species raise the possibility of a host specialization in $\mathrm{Po}$ lymyxa linked to the ribotype previously described. This possibility is of major importance in improving the understanding of the specific interactions between $P$. graminis and viruses. Therefore, specific and sensitive tools such as restriction fragment length polymorphism (RFLP) analysis of polymerase chain reaction (PCR)-amplified rDNA, and nested, multiplex, and real-time quantitative PCR assays were developed to discriminate between $P$. graminis f. sp. temperata and $P$. graminis $\mathrm{f}$. sp. tepida, and to study the host specialization of $P$. graminis special forms. These methods were targeted on two cereal species cultivated mainly in temperate areas - barley and wheat - and grown on soils infested by bymo- and furoviruses.

\section{MATERIALS AND METHODS}

Origin of $P$. graminis inocula. $P$. graminis inocula were obtained from plants grown under controlled conditions on infested soils or collected in fields. Seven Belgian soil samples were collected in fields at Baisy-Thy, Flavion, Gembloux, Malines, Marbais, Marneffe, and Ramillies. Their sampling was based on a previous survey of the distribution of Barley yellow mosaic virus (BaYMV) and Barley mild mosaic virus (BaMMV) in Belgium and was targeted at soilborne viruses and $P$. graminis-prone areas. In addition, one French soil (Chambon-sur-Cisse) was studied. Three infested soils were used for the precise characterization of $P$. graminis inocula. The soil sample collected in France at Chambon-sur-Cisse is from an experimental field of ARVALIS (Technical Institute for Cereals and Forage, France) with a wheat monoculture since the 1990s and known to be infested by mosaic viruses of wheat $(25,26)$. The Gembloux soil is from an experimental field of CRA-W (Centre Wallon de Recherches Agronomiques, Gembloux, Belgium) infested by BaMMV and BaYMV (24) and in which barley cultivars have been grown since the 1980s with wheat and rye cultivars since 2004. In the soil sample from a farmer field at Flavion (Belgium), mosaic symptoms were observed for the first time in Belgium in 2004, and furoviruses and the Wheat spindle streak mosaic virus (WSSMV) were detected $(25,26)$.

After sampling, the soils were dried at room temperature, ground to dust, and diluted to $1: 5 \mathrm{vol} / \mathrm{vol}$ with sterile quartz (1 to $2 \mathrm{~mm}$ ) to reduce the competition between soil organisms and obtain soil with a structure conducive to $P$. graminis development (18). The soil-quartz mixtures were distributed in pots. Barley cvs. Carola (NORDSAAT Saatzuchtgesellschaft mbH, Bohnshausen, Germany), Tiffany (Saatzucht Josef Breun GdbR, Herzogenaurach, Germany), and Tokyo (Limagrain Nickerson $\mathrm{GmbH}$, Edemissen, Germany), as well as wheat cvs. Cezanne (Limagrain Verneuil Holding, Saint Beauzire, France) and Savannah (Advanta Seeds UK Ltd., Lincolnshire, UK) were used as bait plants. The seeds were disinfected by soaking for 5 $\mathrm{min}$ in $2.5 \%$ sodium hypochlorite solution, followed by rinsing under tap water for 1 $\mathrm{h}$. The seeds were pregerminated on moistened filter paper at $22^{\circ} \mathrm{C}$ for 2 days before transferring to the pots, with one seed per pot. The plants were grown under controlled conditions with a 12-h photoperiod at temperatures of 12 to $14^{\circ} \mathrm{C}$ or 16 to $18^{\circ} \mathrm{C}$ (night-day) and were watered with a modified Hoagland nutrient solution at $\mathrm{pH}$ 7.2 (14). The plants were removed after 6 
to 19 weeks of growth to check $P$. graminis infection by PCR (13).

In addition, barley and wheat plants were collected in 2003 and 2004 from Chambon-sur-Cisse, Flavion, Gembloux, and Malines fields. A minimum of 10 plants were checked for $P$. graminis presence except for those from the Malines farmer field, from which a composite sample of plants showing mosaic symptoms was analyzed. After collecting, the roots of plants were washed individually and the plant material (roots and leaves) was stored at $-20^{\circ} \mathrm{C}$ until further analysis.

DNA extraction. Total DNA was extracted from plant samples, which consisted of $300 \mathrm{mg}$ of frozen roots, using FastDNA kit (QBIOgene, MP Biomedicals, Illkirch, France) and the FastPrep system following the protocol described by Legrève et al. (13). The DNA extracts were diluted to 1:10 in Tris-EDTA solution (1 M Tris, 0.5 $\mathrm{M} \mathrm{Na}_{2}$ EDTA, $\mathrm{pH} 8$ ) and stored at $-20^{\circ} \mathrm{C}$ until further analysis.

Broad-spectrum detection of Polymyxa species. The detection of $P$. graminis in the roots was performed from DNA extracts by PCR using the broad-spectrum detection method with Psp1 and Psp2rev primers (13) (Table 1, Fig. 1).

rDNA sequencing of $P$. graminis from barley and wheat. In order to characterize the $P$. graminis infecting barley and wheat plants (Table 2), amplified PCR products using the broad-spectrum detection method were sequenced directly or after cloning into the pCR2.1-TOPO vector for TOPO TA cloning kit (Invitrogen, Merelbeke, Belgium). The obtained plasmids were used to transform competent cells of Escherichia coli (One Shot cells, Invitrogen) following the manufacturer's instructions. The plasmid DNA from successfully transformed cells was extracted and purified using the QIAprep Spin Miniprep kit (QIAGEN, Antwerpen, Belgium) following the manufacturer's instructions. The sequencing was processed using the prim- ers Psp1 and Psp2rev separately, using a Quick Start kit and CEQTM $2000 \times \mathrm{L}$ DNA Analysis System (Beckman Coulter, Fullerton, CA, USA). The forward and reverse sequences obtained from each sample were assembled.

Sequence comparison and determination of the conserved regions. The sequences obtained, including the internal transcribed spacers one (ITS1) region known to show specificity among the special forms (11), were aligned with published sequences of $P$. graminis f. sp. temperata and $P$. graminis f. sp. tepida (accession numbers AJ311572, AJ311573, AJ311574, Y12824, and Y12826) using the ClustalW program of the European Molecular Biology Laboratory (EMBL, online). This alignment allowed the sequence variations between the two studied $P$. graminis special forms to be determined.

Restriction fragment length polymorphism (RFLP). On the basis of sequences specific to $P$. graminis f. sp. temperata and $P$. graminis $\mathrm{f}$. sp. tepida, the restriction enzymes $N r u \mathrm{I}$ and SalI were selected specifically to cut rDNA of $P$. graminis $\mathrm{f}$. sp. temperata in the ITS1 region, or rDNA of $P$. graminis f. sp. tepida in nuclear small rDNA 18S, respectively (Fig. 1, Table 1), and were used to digest PCR products from the broad-spectrum detection of $\mathrm{Po}$ lymyxa species (13). Each 25- $\mu$ l reaction volume was prepared with $10.5 \mu \mathrm{l}$ of diethyl pyrocarbonate (DEPC)-treated water, $2.5 \mu \mathrm{l} 10 \times$ SuRE/Cut Buffer (Buffer B for NruI and Buffer H for SalI in order to obtain maximal activity of enzymes), $10 \mu \mathrm{l}$ of amplified DNA, and $2 \mu \mathrm{l}$ of restriction enzyme (Roche, Villvoorde, Belgium) (10 $\mathrm{U} / \mu \mathrm{l})$. This mixture was incubated overnight at $37^{\circ} \mathrm{C}$, and the next day the enzymes were inactivated by $15 \mathrm{~min}$ at $65^{\circ} \mathrm{C}$. After this, $2 \mu \mathrm{l}$ of loading buffer was added and the products were loaded on $2 \%$ agarose gel in Tris Borate-EDTA buffer. The electrophoresis was performed in Sub-Cell
GT Agarose Gel Electrophoresis Systems (Bio-Rad, Nazareth, Belgium). After ethidium bromide staining, the bands of DNA were visualized using the Gel Doc 2000 (Bio-Rad).

Nested and multiplex PCR. Two primer pairs were designed on the basis of the ITS1 region specific to $P$. graminis $\mathrm{f}$. sp. temperata or $P$. graminis $\mathrm{f}$. sp. tepida using the "eprimer3" WEMBOSS program (8) (Fig. 1, Table 1). For the nested PCR, the broad-spectrum detection method for Polymyxa species was performed as described by Legrève et al. (13), except that only $0.1 \mu \mathrm{l}$ of each primer $(20 \mu \mathrm{M})$ was used and only 10 cycles performed. Afterward, $0.5 \mu \mathrm{l}$ of each internal primer (PgtempN-F/PgtempN-R or PgtepN-F/ PgtepN-R) was added to the tube, and the PCR was conducted under the same conditions for a further 25 cycles. The three primer pairs were also tested in multiplex PCR under the same conditions over 35 cycles.

Real-time quantitative PCR. One set of primers and Taqman probe specific to $P$. graminis f. sp. temperata and another set specific to $P$. graminis $\mathrm{f}$. sp. tepida were designed using the Beacon Designer 3.0 program of Biosoft International (Corina Way, CA, USA) (Fig. 1, Table 1). The targeted region of the rDNA was moved to the ITS2 in order to increase the efficiency of the quantification of $P$. graminis $\mathrm{f}$. $\mathrm{sp}$. temperata. Real-time PCR protocol was initially optimized by varying product quantities, times, and temperatures applied in the quantitative PCR reaction. DNA was extracted from $300 \mathrm{mg}$ of roots from all samples. The mixture for the real-time PCR was prepared with $12.5 \mu \mathrm{l}$ of $2 \times \mathrm{iQ}^{\mathrm{TM}}$ Supermix (Bio-Rad, Nazareth, Belgium), $2.5 \mu \mathrm{l}$ of reverse primer at $300 \mathrm{nM}, 2.5 \mu \mathrm{l}$ of forward primer at $300 \mathrm{nM}, 2.5 \mu \mathrm{l}$ of probe at $100 \mathrm{nM}, 2.5 \mu \mathrm{l}$ of DEPC-treated water, and $2.5 \mu \mathrm{l}$ of DNA extract diluted 1:10. The amplification reaction was conducted on the Bio-Rad iCycler as follows:

Table 1. Sequences of primers, Taqman probes, and restriction enzymes designed for Polymyxa graminis f. sp. temperata and P. graminis f. sp. tepida detection and quantification (see Figure 1 for their location)

\begin{tabular}{|c|c|c|}
\hline Designation & Sequence $\left(5^{\prime}-3^{\prime}\right)$ & Detection methods ${ }^{a}$ \\
\hline $\begin{array}{l}\text { Psp1 } \\
\text { Psp2rev }\end{array}$ & $\begin{array}{l}\text { TAGACGCAGGTCATCAACCT } \\
\text { AGGGCTCTCGAAAGCGCAA }\end{array}$ & Broad-spectrum PCR of Polymyxa species (13) \\
\hline NruI & TCG $\downarrow C G A$ & RFLP for $P$. graminis f. sp. temperata \\
\hline SalI & G $\downarrow$ TCGAC & RFLP for $P$. graminis f. sp. tepida \\
\hline $\begin{array}{l}\text { PgtempN-F } \\
\text { PgtempN-R }\end{array}$ & $\begin{array}{l}\text { AGCGTTGAATTGGTCTTGGT } \\
\text { TAGCCAATTCTCCCGAGTTC }\end{array}$ & Nested \& multiplex PCR for $P$. graminis f. sp. temperata \\
\hline $\begin{array}{l}\text { PgtepN-F } \\
\text { PgtepN-R }\end{array}$ & $\begin{array}{l}\text { TAGCGTTGAATGGTTGTTGC } \\
\text { TTCGACTTTAGCCACCGTTT }\end{array}$ & Nested \& multiplex PCR for $P$. graminis f. sp. tepida \\
\hline $\begin{array}{l}\text { Pgtemp-F } \\
\text { Pgtemp-R } \\
\text { Pgtemp-S }\end{array}$ & $\begin{array}{l}\text { GGAGTTGCAGCCCGCATG } \\
\text { CGCCATGACGGATTGTCGTT } \\
\text { Texas red-5'AGTCAGCACGTCGGCCAAAGTCCA3'-BHQ-2 }\end{array}$ & Real-time quantitative PCR for $P$. graminis f. sp. temperata \\
\hline $\begin{array}{l}\text { Pgtep1-F } \\
\text { Pgtep1-R } \\
\text { Pgtep1-S }\end{array}$ & $\begin{array}{l}\text { AATGTGGATCGTCTCTGTTGCTG } \\
\text { CACCGTTTTGATCCAATTCGTGAA } \\
\text { FAM-5'CGGGATGGAACGCCCTCGTGGTGG3'- BHQ-1 }\end{array}$ & Real-time quantitative PCR for $P$. graminis f. sp. tepida \\
\hline
\end{tabular}

a $\mathrm{PCR}=$ polymerase chain reaction; RFLP = restriction fragment length polymorphism. 
an initial denaturation at $95^{\circ} \mathrm{C}$ for $3 \mathrm{~min}$, 40 cycles each composed of (i) $95^{\circ} \mathrm{C}$ for $15 \mathrm{~s}$ and (ii) $60^{\circ} \mathrm{C}$ for $1 \mathrm{~min}$. In each set of real-time PCR, two repetitions were performed for all tested samples.

DNA standards were prepared from PCR products from both $P$. graminis special forms and cloned in the pCR2.1TOPO vector for TOPO TA cloning kit (Invitrogen) as detailed above, from PCR products obtained using the broadspectrum detection of Polymyxa species (13), or using Psp1/ITS4 primers (ITS4 primer designed by White et al. [30] and targeting the 5 ' region of $28 \mathrm{~S}$ gene; Fig. 1). The clone containing the PCR product obtained using Psp1/Psp2rev primers on wheat cv. Cezanne grown under controlled conditions on Marbais soil (accession number AM259277, Table 2) was used as the DNA standard for $P$. graminis $\mathrm{f}$. sp. tepida. The clone containing the PCR product obtained using Psp1/ITS4 primers on barley cv. Tiffany grown under controlled conditions on Gembloux soil was used as the DNA standard for $P$. graminis f. sp. temperata. The concentration in

Table 2. Origin of Polymyxa graminis sequences

\begin{tabular}{llll}
\hline Cereal & Soil, year $^{\mathbf{a}}$ & Accession number & P. graminis $\mathbf{f}$ sp. \\
\hline Barley cv. Carola & Gembloux, 04/2003* & AM259281 & temperata \\
Barley cv. Carola & Gembloux, 2003 & AM259280 & temperata \\
Barley cv. Carola & Gembloux, 2004 & AM259276 & temperata \\
Barley cv. Tokyo & Marneffe, 2003 & AM259279 & temperata \\
Barley cv. Tokyo & Marneffe, 2004 & AM259275 & temperata \\
Wheat cv. Cezanne & Baisy-Thy (Genappe), 2003 & AM259283 & tepida \\
Wheat cv. Cezanne & Marbais, 2003 & AM259277 & tepida \\
Wheat cv. Cezanne & Ramillies, 2003 & AM259282 & tepida \\
Wheat cv. Folio & Malines, 04/2004* & AM259284 & tepida \\
Wheat cv. Savannah & Marbais, 2003 & AM259278 & tepida \\
\hline
\end{tabular}

${ }^{a}$ Samples marked with an asterisk were collected in fields, whereas other samples were obtained under controlled conditions.

(A) P. graminis f.sp. temperata (Y12824)

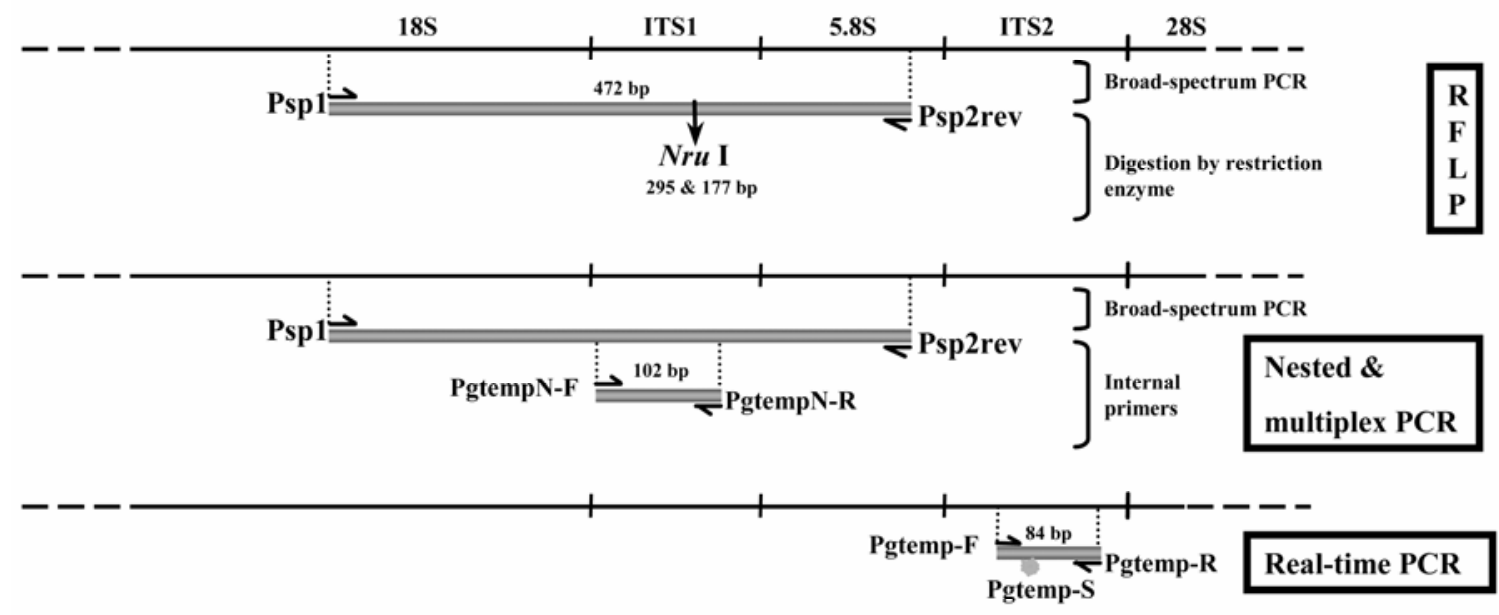

(B) P. graminis f.sp. tepida (Y12826)

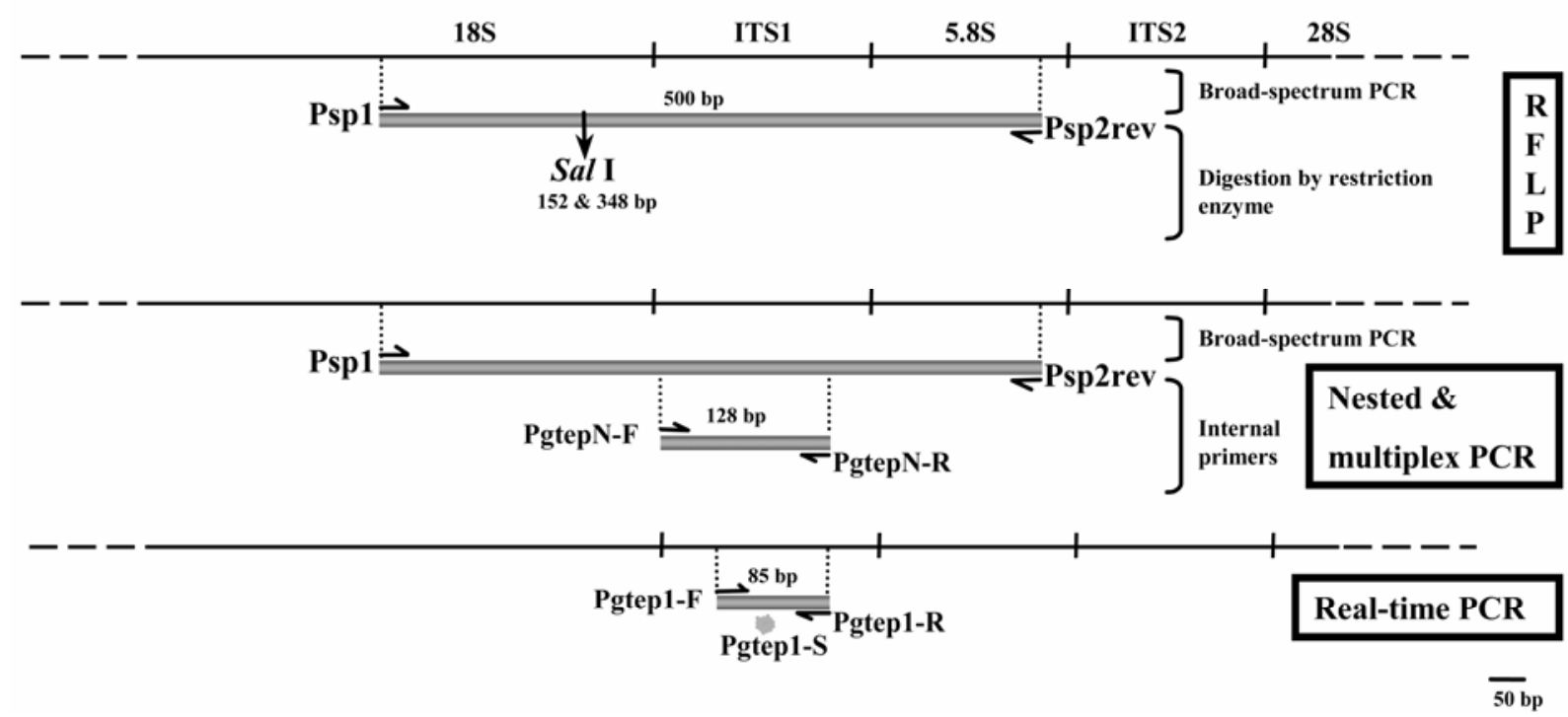

Fig. 1. Location on Polymyxa graminis genome of restriction enzyme cleavage sites and primers used in broad-spectrum polymerase chain reaction (PCR) for Polymyxa species, in restriction fragment length polymorphism (RFLP) and nested, multiplex, and real-time PCR for P. graminis f. sp. temperata (A) and P. graminis f. sp. tepida (B) detection and quantification (see Table 1 for their sequence). 
plasmid DNA (ng/ $\mu \mathrm{l})$ was measured with a spectrophotometer (22). Four serial dilutions of the standard chosen were used in each reaction for obtaining the standard curve, allowing PCR efficiency to be determined and the relative quantities of DNA in each sample tested to be calculated.

In order to evaluate the relative concentration of the DNA quantities measured by real-time PCR in the standards or in the root samples compared to the quantities of sporosori, sporosore suspensions were produced from barley and wheat roots infected by $P$. graminis f. sp. temperata and $P$. graminis f. sp. tepida, respectively, as described by Legrève et al. (14). DNA extraction and real-time quantitative PCR were then performed as described above for four serial dilutions of known quantities of sporosori.

The specificity of all primers and probes designed for nested, multiplex, and realtime PCR was assessed using BLAST software (3).

The specificity of the methods to $P$. graminis f. sp. temperata or $P$. graminis $\mathrm{f}$. sp. tepida was also tested by including DNA extracts from reference isolates of $P$. graminis $\mathrm{f}$. sp. tropicalis and $P$. graminis $\mathrm{f}$. sp. subtropicalis (MUCL references 43177 and 43182, respectively) (11).

Microscopic observations of $\boldsymbol{P}$. graminis. Root samples were stained in aniline blue lactophenol and observed microscopically in order to analyze the development stage of $P$. graminis.

\section{RESULTS}

Detection and identification of $P$. graminis f. sp. temperata and $P$. graminis f. sp. tepida. $P$. graminis was detected by PCR using the broad-spectrum detection method (13) in barley and wheat plants grown on six Belgian soils. The sequencing of PCR products from these samples provided 10 sequences, which have been deposited at the EMBL under the accession numbers AM259275, AM259276, AM259277, AM259278, AM259279, AM259280, AM259281, AM259282, AM259283, and AM259284 (Table 2). These sequences were aligned with the sequences already known for $P$. graminis. The five sequences from $P$. graminis on barley were $100 \%$ homologous to the published sequence of $P$. graminis f. sp. temperata (accession number Y12824), except the one from an isolate from Marneffe for which one base differed from the 132 bases in the ITS1 at position 99 (1 $\mathrm{T}$ instead of $1 \mathrm{~A}$; accession number AM259275, Table 2). The five other sequences obtained from $P$. graminis on wheat were very close to the published sequence of $P$. graminis f. sp. tepida (accession number Y12826), but one base was missed at the 113 position in the ITS1. For the sequence from the Marbais isolate (accession number AM259277, Table 2), two other bases differed at positions 96 and 103 of the ITS1. This characterization study therefore revealed that the two special forms hitherto described in temperate areas are present in Belgium: $P$. graminis $\mathrm{f}$. sp. temperata on barley plants and $P$. graminis f. sp. tepida on wheat.

Development of detection methods. On the basis of the sequences obtained from our isolates and the sequences published for each special form, three detection methods specific to $P$. graminis $\mathrm{f}$. $\mathrm{sp}$. temperata and $P$. graminis f. sp. tepida were developed. RFLP and nested and multiplex PCR were conducted to identify the special form present in DNA extracts from the 10 samples of PCR products (Table 2). In the RFLP method, two fragments of 295 and 177 bp were obtained after the digestion of $P$. graminis $\mathrm{f}$. sp. temperata using NruI and the other two of 152 and $348 \mathrm{bp}$ after the digestion of $P$. graminis $\mathrm{f}$. sp. tepida using SalI. The primers used in the nested and multiplex PCR allowed amplification of a region of $102 \mathrm{bp}$ for $P$. graminis f. sp. temperata and a region of 128 bp for $P$. graminis f. sp. tepida. The sizes of the DNA fragments obtained by RFLP and nested or multiplex PCR corresponded to the expected profiles from the sequences known for these two special forms. It was shown that the three methods target the specific sequences of $P$. graminis f. sp. temperata and $P$. graminis f. sp. tepida since they allowed identification of and discrimination between $P$. graminis $\mathrm{f}$. sp. temperata and $P$. graminis f. sp. tepida in some samples on barley and wheat or the detection of both in mixtures (Fig. 2). In addition, no cross-reaction with $P$. graminis f. sp. subtropicalis and $P$. graminis f. sp. tropicalis was observed.

The characterization of $P$. graminis inocula using the above methods revealed the identification of $P$. graminis f. sp. temperata on barley plants grown on some soils (Gembloux and Marneffe soils for example) and the identification of $P$. graminis f. sp. tepida on wheat grown on other soils (Baisy-Thy, Chambon-surCisse, Flavion, Malines, Marbais, and Ramillies soils). In some fields at Chambon-sur-Cisse and Flavion, both special forms were detected on wheat plants (Table 3).

In order to answer whether there is host specialization of $P$. graminis f. sp. temperata and $P$. graminis f. sp. tepida on barley and wheat, plants of both species were grown under controlled conditions on Belgian soils collected at Gembloux and Flavion, and on French soil collected at Chambon-sur-Cisse; the characterization of $P$. graminis special forms was done after 12 weeks of growth in the infected plants. This study revealed that different associations of $P$. graminis f. sp. temperata and $P$. graminis f. sp. tepida occurred on barley and wheat plants and the frequencies of detection of each special form differed among soils and plant species (Table 3). Both special forms were isolated from plants grown in each of the three tested soils at a very low frequency, but $P$. graminis f. sp. temperata was more frequent on barley than on wheat, whereas $P$. graminis $\mathrm{f}$. sp. tepida was more often detected on wheat. This study demonstrated the specialization of $P$. graminis special forms on cereal species according to an independence test (chi-square test). In order to assess the multiplication rate of $P$. graminis $\mathrm{f}$. $\mathrm{sp}$. temperata and $P$. graminis f. sp. tepida in barley and wheat, a realtime PCR method was developed to quantify infection by these two special forms.

Quantification of $P$. graminis special forms. The quantification of each special form by real-time quantitative PCR using specific primers and Taqman probes was assayed relative to "standard DNAs" built with specific DNA fragments of $P$. graminis $\mathrm{f}$. sp. temperata or $P$. graminis $\mathrm{f}$. sp. tepida cloned into plasmids. The kinetics of the fluorescence curves for four serial dilutions of the standards with DNA from $P$. graminis f. sp. tepida (Fig. 3) or $P$. graminis $\mathrm{f}$. sp. temperata (data not shown) showed an efficiency of 92 to $98 \%$ and 90 to $93 \%$, respectively. Those obtained for DNA from $P$. graminis-infected plants displayed the same profiles as shown in Figure 3 for $P$. graminis f. sp. tepida. No fluorescence was recorded in the presence of DNA extracted from healthy root tissues, and there was no cross-reaction between $P$. graminis f. sp. temperata and $P$. graminis f. sp. tepida or with $P$. graminis $\mathrm{f}$. sp. tropicalis and $P$. graminis f. sp. subtropicalis. In addition, it was shown that the presence of DNA from the other special form did not alter the real-time PCR assay, since the quantification of $P$. graminis f. sp. temperata or of $P$. graminis f. sp. tepida in a sample prepared with a mixture of DNA from both special forms gave the same threshold cycle (CT) values as those obtained with the same quantity of DNA from the respective form used alone. This is illustrated for $P$. graminis f. sp. tepida in Figure 3, but it was also tested for $P$. graminis f. sp. temperata.

Host specialization. The proportions of $P$. graminis f. sp. temperata and $P$. graminis $\mathrm{f}$. sp. tepida determined by realtime quantitative PCR assays in barley and wheat plants grown on two soils were calculated by comparison with the values obtained for DNA from the clones (used as standards) and from known quantities of sporosori (Table 4). From the Chambonsur-Cisse soil, the sporosori concentrations of $P$. graminis $\mathrm{f}$. sp. temperata were on average $\sim 5,000$ times higher on barley than on wheat plants, and from the Gembloux soil they were on average 500 times higher on barley. From both soils, the relative concentrations of $P$. graminis f. sp. tepida were on average $\sim 100$ times higher on wheat than on barley plants. The as- 
sessment of the relative quantities of sporosori shows that the concentration of $P$. graminis f. sp. temperata on barley grown on the Gembloux soil was greater than the quantity of $P$. graminis f. sp. tepida on wheat. This difference was less important for plants grown on the Chambon-sur-Cisse soil, for which the inoculum potential by $P$. graminis $\mathrm{f}$. sp. tepida appeared to be higher than in the Gembloux soil. No clear differences were observed in relation to the conditions and length of growth.

Microscopic observations of stained roots from barley and wheat plants grown
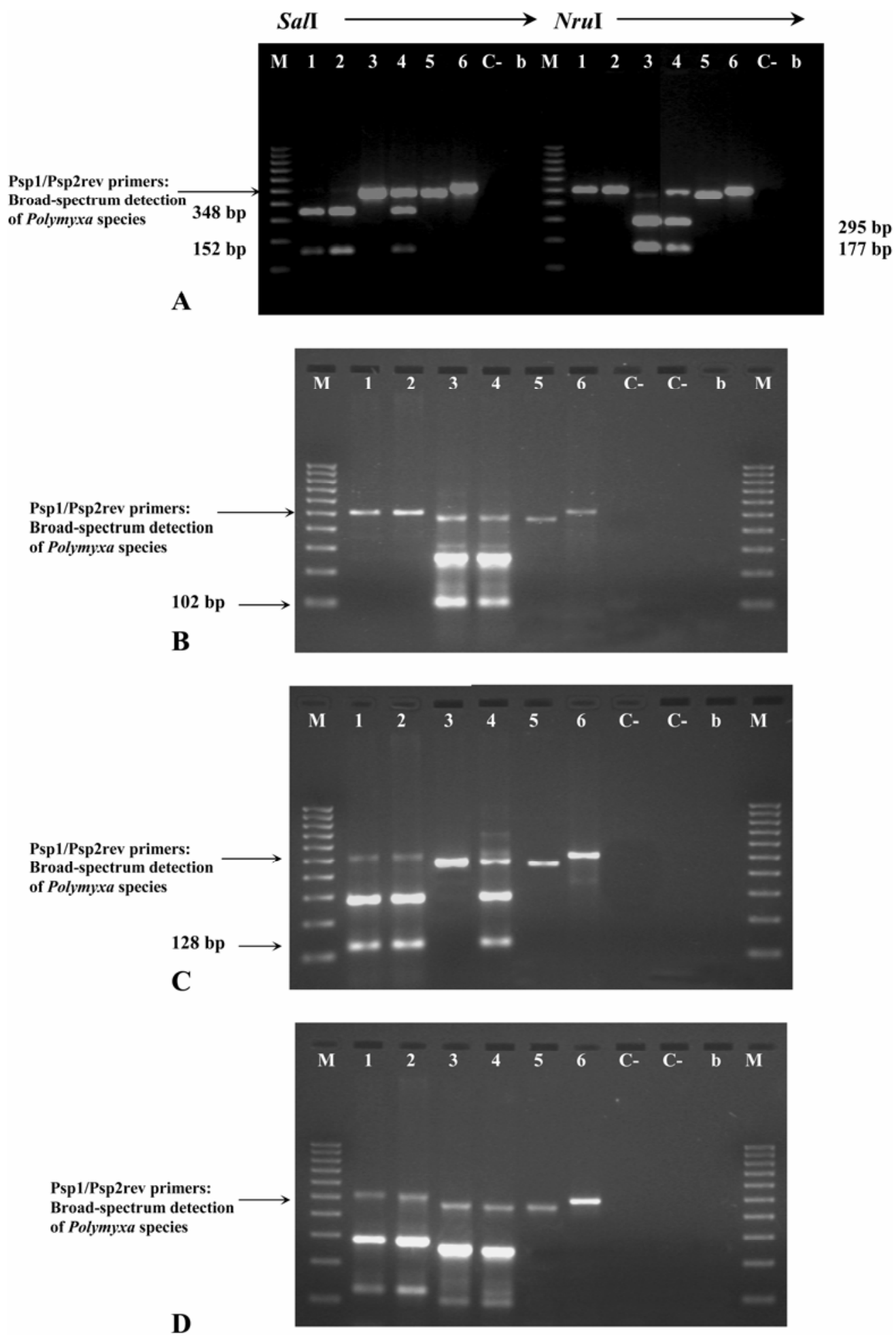

Fig. 2. A, Restriction fragment length polymorphism (RFLP), using SalI and NruI restriction enzymes, from polymerase chain reaction (PCR) products obtained with Psp1 and Psp2rev primers. B and C, DNA profiles produced after nested PCR for detection of Polymyxa graminis f. sp. temperata and $P$. graminis f. sp. tepida, respectively. D, DNA profiles produced after multiplex PCR for identification of $P$. graminis f. sp. temperata and $P$. graminis f. sp. tepida. Lanes: (1) roots of wheat cv. Cezanne grown in Flavion soil in pot (Belgium, 16-18 ${ }^{\circ} \mathrm{C}, 8$ weeks); (2) roots of wheat cv. Cezanne grown in Chambonsur-Cisse soil in pot (France, $16-18^{\circ} \mathrm{C}, 8$ weeks); (3) roots of barley cv. Tiffany grown in Gembloux soil in pot (Belgium, $16-18^{\circ} \mathrm{C}, 8$ weeks); $(4)$ mixture of the samples loaded in lanes 1 and 3; (5) and (6) P. graminis f. sp. tropicalis and P. graminis f. sp. subtropicalis, MUCL references 43177 and 43182 , respectively; (C-) negative control = DNA extracted from root tissue of healthy barley and wheat plants grown in sterile sand; (b) blank = products used in PCR reaction with DEPC-treated water (without plant sample), and (M) size marker: EZ Load 100-bp Molecular Ruler (Bio-Rad, Nazareth, Belgium). 
Table 3. Infection frequencies of Polymyxa graminis f. sp. temperata and P. graminis f. sp. tepida on barley (cv. Tiffany) and wheat (cv. Cezanne) plants collected in 2004 from Chambon-sur-Cisse, Flavion, and Gembloux fields and other plants grown under controlled conditions in pots on soils collected in these three fields $\left(16-18^{\circ} \mathrm{C}, 12 \text { weeks of growth }\right)^{\mathrm{a}}$

\begin{tabular}{|c|c|c|c|c|c|c|}
\hline & \multirow[b]{2}{*}{ Soils } & \multirow[b]{2}{*}{ Cereal } & \multirow{2}{*}{$\begin{array}{l}\text { Number } \\
\text { of plants }\end{array}$} & \multicolumn{3}{|c|}{ Frequency of $P$. graminis f. sp. (\%) } \\
\hline & & & & temperata & tepida & Both \\
\hline \multirow[t]{3}{*}{ Field } & Chambon & Wheat & 10 & 0 & 80 & 20 \\
\hline & Flavion & Wheat & 10 & 0 & 80 & 20 \\
\hline & Gembloux & Barley & 13 & 100 & 0 & 0 \\
\hline \multirow{5}{*}{$\begin{array}{l}\text { Under controlled } \\
\text { conditions }\end{array}$} & Chambon & Barley & 6 & 83 & 0 & 17 \\
\hline & & Wheat & 10 & 0 & 90 & 10 \\
\hline & Flavion & Wheat & 4 & 0 & 75 & 25 \\
\hline & Gembloux & Barley & 12 & 100 & 0 & 0 \\
\hline & & Wheat & 5 & 0 & 80 & 20 \\
\hline
\end{tabular}

a Characterization of the $P$. graminis special forms was done using nested and multiplex polymerase chain reaction described in this study.
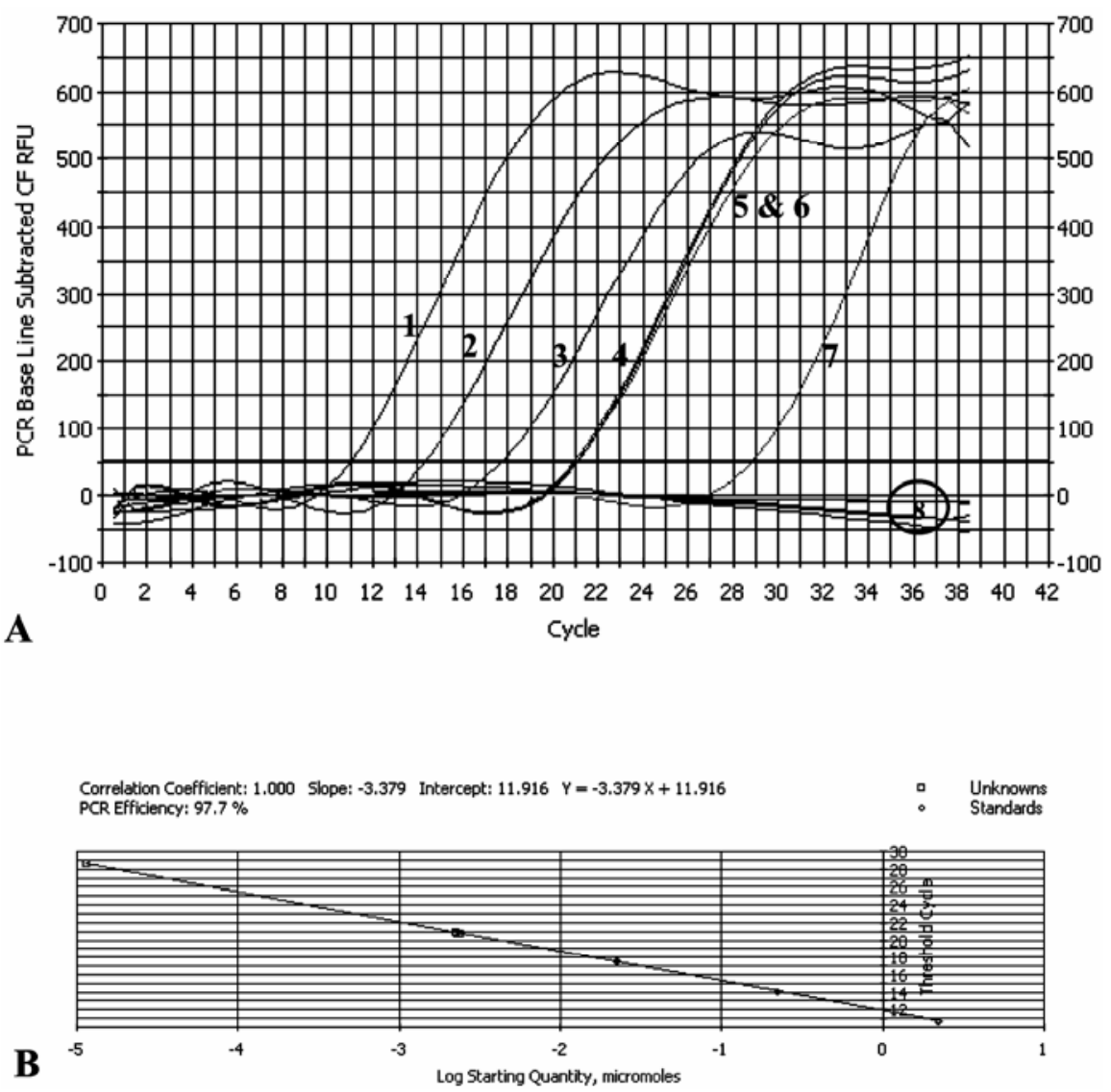

Fig. 3. Real-time quantitative polymerase chain reaction (PCR) assay for Polymyxa graminis f. sp. tepida. A, Showing the increase in fluorescence with time (Cycle) of accumulated PCR products. B, Standard curve obtained from results of four serial dilutions of standard sample. Samples in: $(1,2,3$, and 4) four serial dilutions of 100 to 100,000 of the standard sample used in each reaction, the clone containing rDNA of $P$. graminis f. sp. tepida from PCR product using Psp1/Psp2rev primers on wheat cv. Cezanne roots grown under controlled conditions in Marbais soil (accession number AM259277, Table 2); (5) roots of wheat cv. Cezanne grown in Chambon-sur-Cisse soil in pot (France, 16-18 ${ }^{\circ} \mathrm{C}, 8$ weeks); (6) mixed DNA of sample (5) and roots of barley cv. Tiffany grown in Gembloux soil in pot (Belgium, $16-18^{\circ} \mathrm{C}, 8$ weeks); (7) roots of wheat cv. Cezanne grown in Flavion soil in pot (Belgium, $16-18^{\circ} \mathrm{C}, 12$ weeks); (8) several samples: roots of barley cv. Tiffany grown in Gembloux soil in pot (Belgium, $16-18^{\circ} \mathrm{C}, 8$ weeks) - P. graminis f. sp. tropicalis and $P$. graminis f. sp. subtropicalis, MUCL references 43177 and 43182 , respectively - negative control $=$ DNA extracted from root tissue of healthy barley and wheat plants grown in sterile sand - and blank = products used in PCR reaction with DEPC-treated water (without plant sample).

under controlled conditions were conducted. $P$. graminis was observed at all development stages on barley plants with a very good multiplication, whereas $P$. graminis was observed on wheat plants with some difficulty and only at the sporosori stage.

\section{DISCUSSION}

For some years, molecular methods have been applied to detect $P$. graminis using PCR $(9,12,13,21,23,29)$. These methods have facilitated the identification of this root parasite, otherwise detected by microscopy or serological methods (ELISA) $(2,7,15)$. Molecular characterization studies also allowed $P$. graminis to be separated into special forms (11). Two of them, $P$. graminis f. sp. temperata and $P$. graminis $\mathrm{f}$. sp. tepida, occur in temperate areas. They are distinguished only by their particular ribotypes, but whether this difference affects their ecology or ability to vector a particular virus is questioned. It was for discrimination and quantification of these two forms that specific techniques had to be developed. Ward et al. (29) have published a PCR method for distinguishing $P$. graminis f. $\mathrm{sp}$. temperata and $P$. graminis $\mathrm{f}$. sp. tepida. The methods developed in this paper allowed both precise detection and/or quantification of the forms that were present. These tools were developed on the basis of the sequences from $P$. graminis inocula, including those occurring in Belgium. Characterization of $P$. graminis present in soils from Belgium and France revealed the occurrence of $P$. graminis f. sp. tepida in both countries, in addition to $P$. graminis $\mathrm{f}$. $\mathrm{sp}$. temperata. Hitherto, $P$. graminis f. sp. tepida had been reported in Canada, France, and the United Kingdom and $P$. graminis f. sp. temperata in Belgium, Canada, China, France, Germany, and the United Kingdom $(11,27)$. This is the first time that $P$. graminis f. sp. tepida has been reported in Belgium.

The sequences obtained on barley correspond to published sequences of $P$. graminis f. sp. temperata, and the sequences on wheat plants correspond to $P$. graminis f. sp. tepida, both with 98 to $100 \%$ homology in the ITS1 region. In order to enlarge the detection threshold of the newly developed tools, restriction enzymes for RFLP and primers for nested PCR were selected to target specific regions for each special form as well as to target common regions among inocula of the same form. In addition, the primers were selected to be usable in a unique multiplex reaction. The efficiency of these tools in detecting and discriminating the special forms by RFLP and nested and multiplex PCR was proven on DNA extracted from reference samples or infected plants. These methods demonstrated the presence of both $P$. graminis f. sp. temperata and $P$. graminis f. sp. tepida in some Belgian and French soils, and even the coinfection of some plants by both special forms. The co-infestation of the two forms in some soils had already been observed by Ward et al. (29) from a field at Kent (United Kingdom). The difference in frequency of detection of the forms on barley and wheat reveals some degree of host specificity, with $P$. graminis f. sp. temperata being more frequent on barley and $P$. graminis f. sp. tepida on wheat.

To determine the relative importance of the special forms in the tested soils and to quantify their host specificity, quantitative PCR assays were designed for each form. 
Table 4. Relative quantification of Polymyxa graminis f. sp. temperata and P. graminis f. sp. tepida in barley cv. Tiffany and wheat cv. Cezanne roots after growing on Chambon-sur-Cisse and Gembloux soils, estimated by real-time quantitative polymerase chain reaction

\begin{tabular}{|c|c|c|c|c|c|c|c|}
\hline \multirow[b]{2}{*}{ Soil } & \multirow[b]{2}{*}{ Cereal } & \multirow{2}{*}{$\begin{array}{c}\text { Temperature } \\
\left({ }^{\circ} \mathbf{C}\right)\end{array}$} & \multirow{2}{*}{$\begin{array}{c}\text { Week incuba- } \\
\text { tion }\end{array}$} & \multicolumn{2}{|c|}{$\begin{array}{l}\text { Relative DNA quantity } \\
\text { of } P \text {. graminis f. sp. (per g of roots) } \\
\text { related to } 1 \mathrm{ng} \text { clone DNA }\end{array}$} & \multicolumn{2}{|c|}{$\begin{array}{c}\text { Estimated sporosori concentration } \\
\text { of } P \text {. graminis } \mathrm{f} . \mathrm{sp} \text {. } \\
\text { (per g of roots) }\end{array}$} \\
\hline & & & & temperata & tepida & temperata & tepida \\
\hline \multirow[t]{10}{*}{ Chambon-sur-Cisse } & Barley & $12-14$ & 9 & 94,000 & 0.4240 & 180,436 & 1,140 \\
\hline & & & 12 & 63,467 & 0.0081 & 121,826 & 22 \\
\hline & & $16-18$ & 9 & 153,333 & 0.2000 & 294,328 & 538 \\
\hline & & & 12 & 47,600 & 0 & 91,370 & 0 \\
\hline & & & 19 & 8,640 & 0.0114 & 16,585 & 31 \\
\hline & Wheat & $12-14$ & 9 & 62 & 20.1333 & 120 & 54,154 \\
\hline & & & 12 & 0 & 53.7332 & 0 & 144,531 \\
\hline & & $16-18$ & 9 & 5 & 26.2666 & 9 & 70,652 \\
\hline & & & 12 & 0 & 1.6400 & 0 & 4,411 \\
\hline & & & 19 & 0 & 0.0253 & 0 & 68 \\
\hline \multirow[t]{8}{*}{ Gembloux } & Barley & $12-14$ & 9 & 10,280 & 0 & 19,733 & 0 \\
\hline & & & 12 & 18,667 & 0 & 35,831 & 0 \\
\hline & & & 19 & 4,773 & 0 & 9,163 & 0 \\
\hline & & $16-18$ & 9 & 16,933 & 0.0012 & 32,504 & 3 \\
\hline & & & 12 & 26,933 & 0 & 51,699 & 0 \\
\hline & Wheat & $12-14$ & 9 & 45 & 0.0580 & 86 & 156 \\
\hline & & & 12 & 6 & 0 & 11 & 0 \\
\hline & & $16-18$ & 9 & 37 & 0.0064 & 70 & 17 \\
\hline
\end{tabular}

The infection of P. graminis f. sp. temperata was significantly higher on barley than on wheat, and the infection of $P$. graminis f. sp. tepida was higher on wheat than on barley. A real difference of host specificity of both special forms was shown quantitatively. This is the first time that these two special forms occurring in temperate areas have been quantified specifically by realtime PCR and a clear segregation between them on the basis of their infection rate of barley and wheat in two soils (Chambonsur-Cisse and Gembloux) shown. The distinct host specificity reveals particular ecological characteristics, which support the distinction of two special forms.

The microscopic observations highlighted that $P$. graminis is more easily observed on barley than on wheat, suggesting a more prolific development and multiplication on barley, but this must be confirmed in the further experiments. A morphological characterization (e.g., spore dimensions) could show differences between $P$. graminis present on barley and the one present on wheat, possibly indicating a correlation with the special form detected.

The results presented in this paper show that $P$. graminis f. sp. temperata and $P$. graminis f. sp. tepida have distinct "preferred" hosts, as suggested and demonstrated for other $P$. graminis isolates by Legrève et al. $(15,16)$, which were later classified as different special forms (11). In view of the more important infection of $P$. graminis f. sp. temperata on barley and $P$. graminis f. sp. tepida on wheat, one should consider whether there is a specialization of the interaction between the $P$. graminis special forms, the transmitted viruses, and the host plants. It is worth noting that bymo- and furoviruses on cereals coexist in some soils, and both $P$. graminis $\mathrm{f}$. sp. temperata and $P$. graminis f. sp. tepida have been detected in such soils. Therefore, studies are being conducted in order to better understand the ability of $P$. graminis $\mathrm{f}$. sp. temperata and $P$. graminis f. sp. tepida to transmit specific viruses.

\section{ACKNOWLEDGMENTS}

This research was funded by the Ministère de la Région wallonne (Belgium), Direction générale de l'Agriculture, Direction de la recherche. The authors are grateful to M. Bonnefoy (ARVALIS, Ouzouer-le-Marché, France) and S. Steyer (CRAW, Gembloux, Belgium) for providing the infested soils and plants.

\section{LITERATURE CITED}

1. Adams, M. J. 2002. The mosaic viruses of barley: Problems and prospects. Pages 105-112 in: Proceedings of the BCPC Conference, Vol. 1, Pests and Diseases 2002. The British Crop Protection Council, Farnham, UK.

2. Adams, M. J., and Jacquier, C. 1994. Infection of cereals and grasses by isolates of Polymyxa graminis (Plasmodiophorales). Ann. Appl. Biol. 125:53-60.

3. Altschul, S. F., Gish, W., Miller, W., Myers, E. W., and Lipman, D. J. 1990. Basic local alignment search tool. J. Mol. Biol. 215:403410 .

4. Archibald, J. A., and Keeling, P. J. 2004. Actin and ubiquitin protein sequences support a Cercozoan/Foraminiferan ancestry for the plasmodiophorid plant pathogens. J. Eukaryot. Microbiol. 51:113-118.

5. Bastin, V., Boute, C., and Maraite, H. 1989. Inoculum potential and host range of Polymyxa graminis. Bull. OEPP/EPPO Bull. 19:541-546.

6. Bulman, S. R., Kuhn, S. F., Marshall, J. W., and Schnepf, E. 2001. A phylogenetic analysis of the SSU rRNA from members of the Plasmodiophorida and Phagomyxida. Protist 152:43-51.

7. Delfosse, P., Reddy, A. S., Legrève, A., Thirumala Devi, K., Abdurahman, M. D., Maraite, H., and Reddy, D. V. R. 2000. Serological methods for detection of Polymyxa graminis, an obligate root parasite and vector of plant viruses. Phytopathology 90:537-545.

8. Devereux, J., Haeberli, P., and Smithies, O. 1984. A comprehensive set of sequence analysis programs for the VAX. Nucleic Acids Res. 12:387-395.

9. Dieryck, B., Delfosse, P., Otto, G., Sauvenier,
X., Bragard, C., and Legrève, A. 2005. Peanut clump virus and Polymyxa graminis interactions with pearl millet and sorghum. Parasitica 61:25-34.

10. Kanyuka, K., Ward, E., and Adams, M. J. 2003. Polymyxa graminis and the cereal viruses it transmits: A research challenge. Mol. Plant Pathol. 4:393-406.

11. Legrève, A., Delfosse, P., and Maraite, $\mathrm{H}$. 2002. Phylogenetic analysis of Polymyxa species based on nuclear 5.8S and internal transcribed spacers ribosomal DNA sequences. Mycol. Res. 106:138-147.

12. Legrève, A., Delfosse, P., Ribonnet, L., Paridaens, A. M., Lurkin, R., and Maraite, $\mathrm{H}$ 2005. Diversity of Polymyxa graminis associated with cereals in West Africa. Parasitica 61:5-10.

13. Legrève, A., Delfosse, P., Van Hese, V., Bragard, C., and Maraite, H. 2003. Broadspectrum detection of Polymyxa species and form species by polymerase chain reaction. Pages 40-43 in: Proc. Sympos. Int. Working Group Plant Viruses Fungal Vectors, 5th. IPS, Zurich, Switzerland. C. M. Rush, and U. Merz, eds. American Society of Sugar Beet Technologists, Denver, CO.

14. Legrève, A., Delfosse, P., Vanpee, B., Goffin, A., and Maraite, H. 1998. Differences in temperature requirements between Polymyxa sp. of Indian origin and Polymyxa graminis and Polymyxa betae from temperate areas. Eur. J. Plant Pathol. 104:195-205.

15. Legrève, A., Vanpee, B., Delfosse, P., and Maraite, H. 2000. Host range of tropical and subtropical isolates of Polymyxa graminis. Eur. J. Plant Pathol. 106:379-389.

16. Legrève, A., Vanpee, B., Risopoulos, J., Ward, E., and Maraite, H. 1996. Characterization of Polymyxa sp. associated with the transmission of Indian peanut clump virus. Pages 157-160 in: Proc. Sympos. Int. Working Group Plant Viruses Fungal Vectors, 3rd. J. L. Sherwood and C. M. Rush, eds. American Society of Sugar Beet Technologists, Denver, CO.

17. Maraite, H. 1991. Transmission of viruses by soil fungi. Pages 67-82 in: Developments in Agricultural and Managed-Forest Ecology 23: Biotic Interactions and Soil-borne Diseases. Proc. Conf. Eur. Foundation Plant Pathol., 1st. A. B. R. Beemster, G. J. Bollen, M. Gerlagh, M. A. Ruissen, B. Schippers, and A. Tempel, eds. Elsevier Science Publishers, Amsterdam. 
18. Maraite, H., Goffart, J. P., and Bastin, V. 1988. Development of a quantitative method for asssessment of Polymyxa graminis Led. inoculum potential in soils. Pages 259-266 in: Integrated Crop Protection in Cereals. Proc. Meeting EC Experts' Group. R. Cavalloro and K. D. Sunderland, eds. Balkema, Rotterdam, Netherlands.

19. Maraite, H., and Legrève, A. 1994. Polymyxa graminis: Vecteur des mosaïques. Pages 15-18 in: Recueil des Communications, Journée Mosaïques des céréales transmises par Polymyxa graminis Led., 07-08.04.94, Blois, France.

20. Morales, F. J., Ward, E., Castano, M., Arroyave, J. A., Lozano, I., and Adams, M. J. 1999. Emergence and partial characterization of rice stripe necrosis virus and its fungus vector in South America. Eur. J. Plant Pathol. 105:643-650.

21. Ratti, C., Budge, G., Ward, L., Clover, G., Rubies-Autonell, C., and Henry, C. 2004. Detection and relative quantification of Soilborne cereal mosaic virus (SBCMV) and Polymyxa graminis in winter wheat using real- time PCR $\left(\operatorname{TaqMan}^{\circledR}\right)$. J. Virol. Methods 122:95-103.

22. Sambrook, J., Fritsch, E. F., and Maniatis, T. 1989. Molecular Cloning: A Laboratory Manual, Vol. 3. 2nd ed., Appendix E.5. Cold Spring Harbor Laboratory, Plainview, NY.

23. Subr, Z. W., Kastirr, U., and Kuhne, T. 2002. Subtractive cloning of DNA from Polymyxa graminis - An obligate parasitic plasmodiophorid. J. Phytopathol. 150:564-568.

24. Vaïanopoulos, C., Legrève, A., Barbier, A., Steyer, S., Maraite, H., and Bragard, C. 2003. Detection of Barley yellow mosaic virus and Barley mild mosaic virus by RT-PCR on resistant barley cultivars. Parasitica 59:67-74.

25. Vaïanopoulos, C., Legrève, A., Lorca, C., Moreau, V., Steyer, S., Maraite, H., and Bragard, C. 2005. Occurrence of bymo- and furoviruses on wheat in Belgium. Parasitica 61:45-52.

26. Vaïanopoulos, C., Legrève, A., Lorca, C., Moreau, V., Steyer, S., Maraite, H., and Bragard, C. 2006. Widespread occurrence of Wheat spindle streak mosaic virus in Belgium. Plant Dis. 90:723-728.
27. Ward, E., and Adams, M. J. 1998. Analysis of ribosomal DNA sequences of Polymyxa species and related fungi and the development of genus- and species-specific PCR primers. Mycol. Res. 102:965-974.

28. Ward, E., Adams, M. J., Mutasa, E. S., Collier, C. R., and Asher, M. J. C. 1994. Characterization of Polymyxa species by restriction analysis of PCR-amplified ribosomal DNA. Plant Pathol. 43:872-877.

29. Ward, E., Kanyuka, K., Motteram, J., Kornyukhin, D., and Adams, M. J. 2005. The use of conventional and quantitative real-time PCR assays for Polymyxa graminis to examine host plant resistance, inoculum levels and intraspecific variation. New Phytol. 165:875885.

30. White, T. J., Bruns, T., Lee, S., and Taylor, J. 1990. Amplification and direct sequencing of ungal ribosomal RNA genes for phylogenetics. Pages 315-322 in: PCR Protocols: A Guide to Methods and Application. M. A. Innis, D. H. Gelfand, J. J. Sninsky, and T. J. White, eds. Academic Press, San Diego, CA. 